\title{
Face as an interactional construct in the context of connectedness and separateness
}

\author{
An empirical approach to culture-specific \\ interpretations of face
}

\author{
Ulrike Schröder \\ Universidade Federal de Minas Gerais
}

\begin{abstract}
In recent work, Arundale proposed a Face Constituting Theory based on the Conjoint Co-Constituting Model of Communication. His main concern is directed towards a shift from the individualistic conception of face and (im)politeness to a non-summative view on communication based on fundamental insights from conversation analysis. Based on two film shootings between German and Brazilian exchange students, which are part of the larger corpus NUCOI, we will take a closer look at moments in which face comes to the fore in the light of (dis)alignment and (dis)affiliation. While in the German example facework is negotiated metacommunicatively, in the Brazilian example facework is calibrated in more subtle ways represented by prosodic and visual cues, which are either given or held back by the co-participants. We will show that these two different patterns may be related to culture-specific construals of face.
\end{abstract}

Keywords: Face Constituting Theory, (dis)alignment, (dis)affiliation, GAT 2, separateness, connectedness, cultural concepts

\section{Introduction}

In recent work, Arundale (2009, 2010, 2013a) proposed his Face Constituting Theory based on a Conjoint Co-constituting Model of Communication. His main concern is directed towards a shift from individualistic conceptions of face and (im)politeness to a non-summative view on communication based on fundamental insights of conversation analysis (Arundale 2010). He also draws great attention to the interplay of connectedness and separateness, a dialectic relation analyzed as a fundamental category of human interaction by Baxter and Montgomery (1996). Finally, a third cornerstone of his theory is his claim that there are culture-specific 
expressions of this dialectic relation forming the basic ingredients for first order emic construals of face which should be distinguished from the second order construals of the researcher's theory on face (Arundale 2013a).

The aim of the following paper is to outline the main proposition of Arundale's Face Constituting Theory (FCT) from a cross-cultural perspective, namely, the understanding of 'face' in terms of an integral epiphenomenon emerging constantly in the course of interaction and as something coordinated and achieved between the interlocutors. I will pay special attention to (dis)affiliation, as well as to (dis)alignment as two concepts of conversation analysis which also deflect the focus from the speaker's 'intentions' to his or her relation with the interlocutor and which are able to substantiate the claim that 'face' can by no means be conceived of in terms of (im)politeness but rather goes beyond such an isolated matter, especially when cultural concepts come into play.

Based on a corpus of two filmed elicited conversations which are part of the larger corpus of the project NUCOI ${ }^{1}$ - namely, one discussion among four Brazilian exchange students and one among five German exchange students - I will take a closer look at two moments in which 'face' comes to the fore in the light of both connectedness and separation, visible on the interaction level by displayed hints of (dis)alignment and (dis)affiliation.

\section{The current debate on the locus of face and its cultural impact}

Especially over the last decade, a pervasive theoretical discussion has been initiated around revisiting the notion of 'face.' ${ }^{2}$ Researchers in the field of intercultural and interactional pragmatics have endeavored to restore the notion of face in the light of the growing recognition of the limits which the concepts of politeness and impoliteness bear when it comes to explaining phenomena of wider scope, be it more complex moments of conversation and situations, multilayered participation frameworks, the multimodal interplay of verbal, vocal and visual plane, or the consideration of cultural background factors. Bargiela-Chiappini (2003) rightly

1. Núcleo de Estudos de Comunicação (Inter-)Cultural em Interação: http://www.letras.ufmg. br/nucleos/nucoi/. The site is also available in English.

2. See the special issues in Journal of Pragmatics: Face in Interaction (Volume 42, Number 8, 2010); Identity Perspectives on Face and (Im)Politeness (Volume 39, Number 4, 2007); About Face (Volume 35, Numbers 10-11, 2003), as well as the special issue in Pragmatics: Relational work in Facebook and discussion boards/fora (Volume 25. Number 1, 2015). See also the volume edited by Francesca Bargiela-Chiappini and Michael Haugh: Face, Communication and Social Interaction (2009). 
remembers the social-ritual origin of Goffman's (1967 [1955]) idea of 'face' and the subsequent narrowing of the post-Goffmanian use of 'face', a transformation afterwards erroneously attributed to Goffman himself. If we take a closer look at Goffman's essay (1967 [1955]) from today's point of view, it seems as if Goffman in fact was oscillating between an essentialist-egological and a social-interactional perspective without dealing with the contradictions inherent to such opposing angles. Hence, on the one hand, he metaphorically turned the concept into an object by describing face in terms of having, maintaining, losing, giving, saving, being in wrong, or out of it (Goffman 1967 [1955], 6-9); on the other hand, he locates face explicitly not in the body but "in the flow of events in the encounter" (ibid., 7) since face constitutes the "traffic rules of social interaction" (ibid., 12), emphasizing that face is only "loan to him [the individual, US] from society" (ibid., 10). Nevertheless, apart from this ultimately indistinct definition, it was Brown and Levinson (1987 [1978]) who not only made Goffman's 'face' popular for pragmatics but also transferred it "into a cognitive model based on Western ethnocentric assumptions such as the existence of a predominantly rational actor and strategic, goal-oriented nature of 'facework' and of social interaction." (Bargiela-Chiappini 2003, 1454) although some researchers believe such criticism would miss the crucial point of Brown and Levinson's broader conception (Kerbrat-Orecchioni 2017, 31-40).

However, Arundale $(1999,2008,2009,2010,2013 a)$ goes beyond a mere criticism of some issues simply left out or neglected by showing that all approaches on (im)politeness finally keep on maintaining an encoding/decoding model of the communication process in which face is conceived in terms of "person-centered attributes" (Arundale 2010, 2086). Without being explicit about this point, Arundale takes up an important issue already discussed by the communication scientist Gerold Ungeheuer (2010 [1983], 1987) in the seventies and eighties. At that time, Ungeheuer advocated a science of communication in its own right. Influenced by Karl Bühler's (1982 [1934]) definition of speech action as a reciprocal guidance for behavior; by George H. Mead's (1967 [1932]) postulate of the emergence of mind and self from the social process of communication by means of symbolic signs in the social theory; as well as by Philipp Wegener's studies (1991 [1885]) of the bidirectional pervasiveness of coordinative action, the pivotal question for Ungeheuer was the particular structure of communicative interaction, being in itself a social action. Yet in the course of the elaboration of his theory, Ungeheuer looked into the shortcomings of the pragmatic theories of his time and questioned the ubiquitous psychological notion of intentions. The latter was being unheedingly transferred to the communication level in the theory of conversational maxims, as well as in speech act theory, without any critical questioning whether these were truly intentions' which were being communicated, and what exactly the hearer was doing with them (Ungeheuer 2010 [1983], 56-62). 
In a quite similar sense, the Conjoint Co-constituting Model of Communication tries to overcome some deeper misconceptions when it holds that face represents a relational and interactional phenomenon which arises in everyday talk or conduct, and should not be conceived as "a psychological construct that is exogenous to language use, but a dyadic accomplishment that is endogenous to using language" (Arundale 2010, 2079). That is why Arundale sees a high potential in conversation analysis for offering new ground for his Face Constituting Theory (FCT) in its radical shift away from the individualistic perspective to the interactional level of co-oriented action. Thus, he brings to the fore some key principles as an anchoring of face: namely (a) 'Interpreting' as a continually evolving activity; (b) the 'Adjacent Placement Principle' linking one person's design or interpretation of the current utterance with the other person's design or interpretation of the prior or the subsequent utterance; (c) the 'Sequential Interpreting Principle' referring to the interpretation of the utterances currently being produced on the basis of the knowledge and expectations, which rise in designing and interpreting prior utterances; and (d) the 'Recipient Design Principle' regarding the multiple ways in which speakers shape their utterances for others by taking into consideration the participant's perspective.

Additionally taking prosodic and visual cues into consideration and departing therefore from a multimodal approach, special attention will be paid to Arundale's dialectic of connectedness and separateness with regard to alignment and affiliation, respectively disalignment and disaffiliation. These concepts have gained a lot of attention in conversation analysis so far, e.g., in analyzing preference organization (Atkinson \& Heritage 1984, 53-56), sequence organization (Stivers 2008, 2013), turn allocation and turn sharing in moments of 'assisted story-telling' (Hayashi 2013; Lerner 1992, 2002; Stivers 2013), as well as in the structural analysis of special genres such as jocular mockery (Haugh 2010, 2017) or complaints (Drew \& Walker 2009), but not too much attention as an ongoing important factor in co-building face.

We will see that the visible tokens of (dis)alignment and (dis)affiliation, as well as their absence can be directly linked to Arundale's (2010,2013a) idea of connection face and separation face which he conceives as being linked dialectically. Following Baxter and Montgomery (1996) and their conception of human interaction, Arundale explains how this means that participants are constantly oscillating between unity and differentiation, "between being a social entity and being individual entities" (Arundale 2009, 42). Note that there are some quite revealing concepts from the field of intercultural communication studies in which the following dialectic categories, amongst others, brought to the fore crucial differences in cultural emphasis which might allude to connectedness and separateness 
in interaction: 'association' and 'dissociation' (Triandis 1984); self-face concern as expressed in self-enhancement style versus other-face concern as expressed in self-effacement style (Ting-Toomey \& Oetzel 2007); as well as empirical results from intercultural pragmatics revealing, e.g. higher 'affiliation' in Spanish as opposed to Swedish conversations at work, pointing to the categories of 'autonomy' and 'affiliation' as void of socio-cultural values which may be filled in by culture-specific content (Bravo 2008; Fant 2006). However, whereas Bravo's concept shows some parallels to Arundale's (2013b, 293), most intercultual approaches' categories, like those of Ting-Toomey or Triandis, represent rather macro-categorical dichotomies for already being culturally biased as a category.

That last issue is also taken up by Arundale (2013a), who points to the impact culture has on face and brings out an important cognitive aspect which would have been left untouched by a mere conversation analytic approach. According to Arundale's view, identifying culture-specific construals of face corresponds to the understanding of the first order, emic conceptualization of face, while FCT's accomodation of the cultural community first order's concept reflects a second order theory. Amongst others, he resorts to Haugh (2007) who gives an example of an emic construal of face in Japanese, where 'place' (basho) represents a pivotal notion for acquiring an emic understanding of how face is interactionally achieved in Japanese culture, and can be defined as "encompassing one's contextually-contingent and discursively enacted social role and position" (Haugh 2007, 660). Thereby, two opposing dimensions come into play forming a dialectic relation: (1) the 'place one belongs' (uchi) and (2) the 'place one stands' (tachiba). While the first one refers to group-based relationships, mainly family and its extension, along with its obligations and dependencies, the second dimension comprises the interactional achievement of one's public persona or social standing including role and status. Haugh refers to cultural concepts choosing a perspective 'from within' as an 'emic construal'.

Note that this perspective is in accordance with the basic assumptions of 'cultural model' and 'cultural conceptualization' as proposed by cultural linguistics, a perspective which should be added as an appropriate understanding of culture at this point: Many intercultural conceptions of culture are frequently concerned with polarizing macro-categories by putting entire cultures on scales as if they were essential, homogeneous, and monolithic entities; second generation conceptions on their part often claim the complete opposite and suggest a mere functional view of contingent, situational, and emergent factors coming into play in situ as a consequence of the transcultural and globalized world.

From an intercultural pragmatics' angle, Kecskes (2014) tries to overcome this dualism of macro- and micro-perspectives by proposing a socio-cognitive 
approach. In a quite similar way, cultural linguistics put together influences from cognitive and anthropological linguistics suggesting a dynamic view of cultural models. Sharifian $(2015,474-476)$ develops the term 'cultural conceptualization' by building on the notion of 'distributed knowledge and cognition' meaning that not all members of a cultural group share the same concepts, additionally emphasizing that cultural cognition embraces the cultural knowledge that emerges from the interaction between members of a cultural group across time and space. Therefore, it has to be seen as constantly being negotiated and renegotiated.

Thus, 'culture' itself might be associated with different kinds of social groups, a view that is also shared by Spencer-Oatey $(2008,3-4)$. That is to say, culture is a term operationlized by a researcher in order to elaborate specific research questions; for our purposes here, culture is primarily constructed in ethnolinguistic terms and manifested through co-occurring regularities within this ethnolinguistic group, such as basic assumptions and values, orientations to life, beliefs, procedures, behavioural conventions, meanings, schemas, metaphors, metonymies, and prototypes. We will come back to this issue in the respective discussion sections of the sequences.

\section{Methodological background}

The empirical data originates from the corpus of the research group NUCOI. ${ }^{3}$ Primarily, the project aims to videotape interactions between participants with different ethnolinguistic as well as those between participants from the same cultural background for comparative purposes. The interactions represent arranged elicited conversations with conversation tasks (Kasper 2008, 287-288; Senft $1995,579-580)$. In order to gain insight into the culture- and language-related reflexive processes displayed by the participants in situ and to make these visible on the (meta)communicative level, cultural and intercultural topics serve as a stimuli for eliciting discussions. The video footage should reveal how the participants co-construct and negotiate these topics as well as how they deal with (pre-)typifications on a verbal, vocal, and, visual plane. Consequently, in line with Henne and Rehbock (2001,26-27), the conversation type might be classified as a (1) non-public, (2) discursive and non-practical, (3) naturally arranged, (4) face-toface interaction (5) in a small group (6) with unprepared participants mostly unknown to one another (7) who are in a symmetrical relationship.

3. The project's website can be visited at: http://www.letras.ufmg.br/nucleos/nucoi/ 
After recording, the videotapes are transcribed in the software program EXMARaLDA $^{4}$ (Schmidt \& Wörner 2009) following the conventions of GAT 2 (Selting et al. 2011). ${ }^{5}$

The examples below stem from my post-doctoral research year at the University of Münster where I filmed four interactions: (1) an interaction between five Brazilian exchange students shortly after the beginning of their exchange program in Germany; (2) an interaction revolving around their real experiences shortly before their return to Brazil; (3) an interaction between five German students shortly before their studies in different European countries; and (4) an interaction between the same students shortly after they have returned to Germany. In both cases, the number of original participants had reduced to four in each second film shooting. In the German case, one participant decided to stay for a longer period abroad, and in the Brazilian case, one participant did not show up at the second shooting. The recorded interactions lasted between one and two hours. Cards asking about the expectations and first experiences in the new culture with respect to university, friendship, romantic relationships, communication, and society served as a stimulus in order to initiate and maintain the conversation. The respective arrangement of the participants of the two film shootings chosen for analysis (interaction 2 and 3) is shown in Figure 1 and 2:

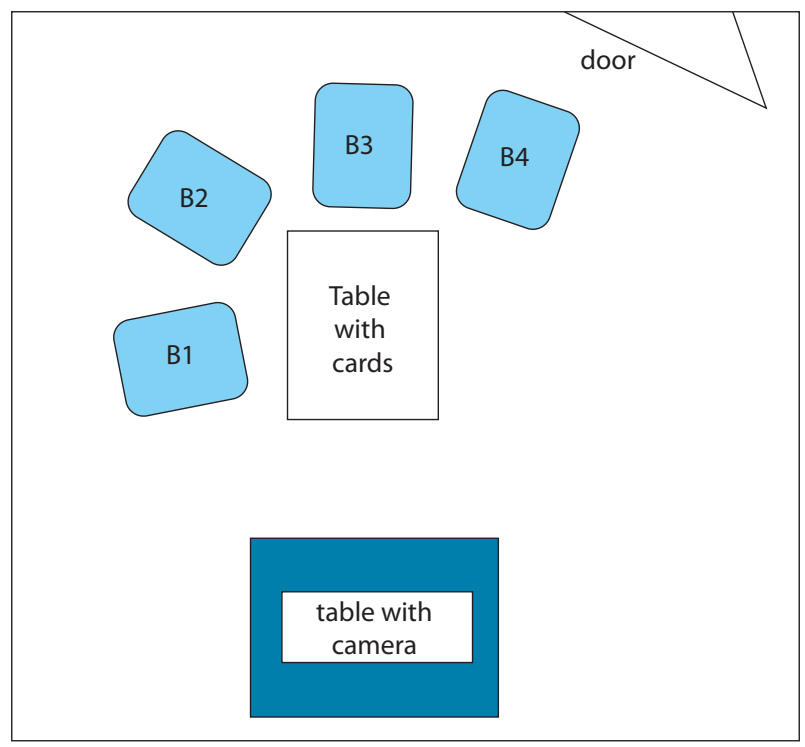

Figure 1. Brazilian film shooting (2) - talk about real experiences (July of 2014)

4. www.exmaralda.org

5. The conventions used here can be found in Section 6 . 


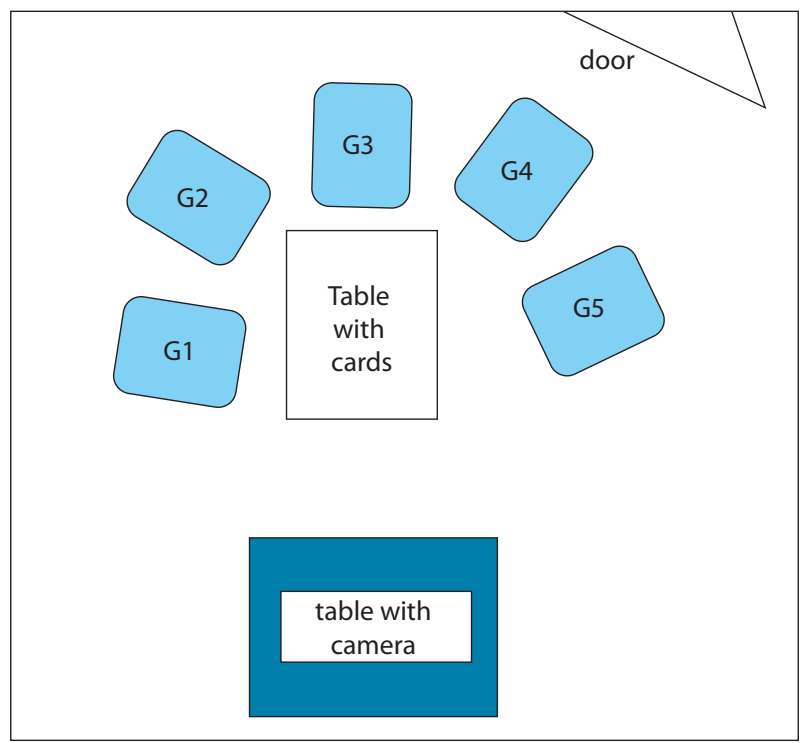

Figure 2. German film shooting (3) - talk about expectations (November of 2013)

\section{Analysis}

\subsection{Brazilian example}

B4 starts reading out loud the next question concerning intercultural situations which the participants experienced in Germany and which involved misunderstandings:



6. The video can be watched on https://drive.google.com/file/d/0B4065pqma9RCOUJWcGZzYSOyMzA/ view? usp=sharing 


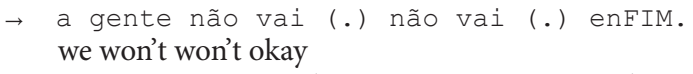


(--) retraí:do assim pra pra poder ajudAr e tudo mais, restrained like to to be able to help and everything

assim tipo Elas me <<gesticulating> botavam numa situação tipo ah-

like they put me in a situation like ah

(.) faz isso aQUI.

do this here

e daí daí é um negócio> sUperdifícil assim?

and then then it's a very difficult thing like

${ }^{\circ} \mathrm{h}$ e (.) tipo (.) uma_uma coisa que poderia ter sido (.) $<$ looking at B2 and círculating hands> fei_feito em três pessoas discu[TINdo, ]

and like a something that could have been done by three persons discussing

$$
\text { B2: [hm aHÃ; ] }
$$

B3: [seria !FÁ!cil de fazer rÁpido; >]

it were easy to do it quickly

B2: [( (unintelligible, 1.4)) ]

B3: [de fazer elas_fazer <<reaching out his hand> FAz tudo; $>$ ] to do they do do everything

B2: $\quad[($ (unintelligible 2.0))

B1: [( (unintelligible 2.0))

B3: aquí e daí a gente disCUTE.

here and there we discuss

$\rightarrow$ e [aí tipo $\uparrow$ PÔ.]

and it's like damn

B2: [aH̃̃, ]

$(--)$



okay fine I do it I did

daí: (cê) chegava para discutir elas (falavam) tá TUdo errado.

and then you came to discuss they said it's all wrong

(.) vamo fazer aGora.

let's do it now

$\rightarrow$ daí tipo (.) $\uparrow$ POxa-

and then like damn

B2: $\rightarrow \quad<<$ p $>$ NOSsa. $>$

my god

B3: (--) foi tipo a 'pion experi'Ência que=eu tive aqui. it was like the worst experience that I had here

e isso é mas tiPo:;

and this is but like

(-) talVEz;

perhaps

eu não sei se isso foi (.) por mal-entenDIdo;

I don't know if this was because of a misunderstanding

sei LÁ mas;

I don't know but

${ }^{\circ}$ hhh (.) é: ;

it's

só não foi uma situação agraDÁvel.

it just wasn't a pleasant situation

(3.3) 


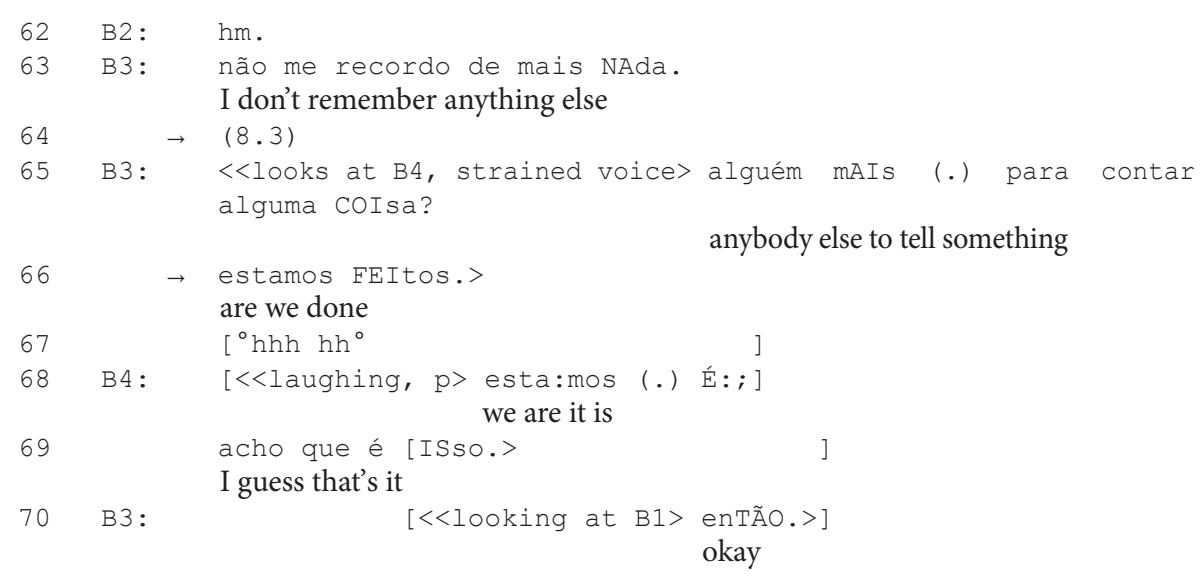

As Stivers $(2013,203)$ shows, storytellings are normally organized around stances, as opposed to adjacency pairs, which in turn are organized around action types. However, what is missing here is some kind of uptake on part of the co-participants. During the whole storytelling of $\mathrm{B} 3$, on the part of the co-participants, neither alignment nor affiliation is realized in an expectable way. None of the interactants adopts an evaluative stance, which is increasingly treated by all members as a noticeable absence - apart from B4, who has already adopted a special kind of 'crossplay' (Goffman 1981, 134) by sending SMS on her cell phone already from the beginning (L12). Let us first draw our attention to possible completion points in which continuers normally occur, and which take "the stance that the speaker of that extended unit should continue talking" (Schegloff 1982, 81); or in which turn transitions point to the engagement of the co-participants. Thus, we can observe an increasing number of possible syntactic completion points with co-occurring prosodic cues and other hints such as pauses (L34, 36, 51, 54, 56, 61, 64), falling intonation (L 33, 34, 34, 50, 51), final accent (L36, 56), lengthening combined with falling intonation $(\mathrm{L} 55,59)$, and also verbal cues like the lexical fillers sei lá (don't know; L33, 58) or tipo (like; L38) which occur when some reaction of the hearer is expected to come in. Nevertheless, in the present case, the speaker has to continue and constructs his turn incrementally, especially when the climax of the story has been told - from line 19 onward - because none of the co-particianpts engages in the interaction. At various points, B3 reaches a possible completion in his storytelling and the absence of mid-telling responses displaying affiliation or simply tokens of acknowledgment displaying alignment is implicitly treated as increasingly problematic. This is especially salient at the climax of the story, in L19, when a first possible completion is reached (and obviously not perceived as such), indicated by the rising to high pitch movement at the end of the line, as well as the short intake of breath at the following line. The next possible completion follows 
in L23 when B3 even explicitly uses a rising intonation, ${ }^{7}$ but neither does he get any continuer (Schegloff 1982, 81) nor does anyone take the turn. So, at these two TCUs, the rising intonation does not serve as a signal for the continuation of the story but to induce, or co-build, a comment. Concurrently, on the visual plane B3 constantly alternates his gaze between the two remaining co-participants, while in turn they neither answer his gaze nor engage in any body movements during the whole sequence; any head nodds are also minimal. In contrast, B3 himself becomes increasingly animated in line with the increasing emotional involvement of his story. There is no nonverbal 'mutual monitoring' (Goodwin 1980), the 'complaining story' (Drew \& Walker 2009, 2405) or 'moral indignation' (Günthner 1999) does not develop in the prototypical way by the construction of 'affective sympathy' because none of the co-participants enter the scene to collabroativley co-construct the storytelling. In the light of the absence of any token of acknowledgment, B3 himself goes on with the story-expansion. Starting in L24, the "emphatic speech style" (Selting 1994) now evolves with deeper emotional involvement, expressed by means of the increasing use of pitch jumps and movements, repeated and reinforced in L25, L46, L49, L52, as well as by the co-occurrence of nonverbal cues displayed on a gestural level and mostly expressed by moving his hand back and forth, as well as up and down. He also gives the expected reaction from the others in form of 'response cries' (Goffman 1981, 100) by himself in line 30 and 33 when he metacommunicatively comments on the ongoing story through the interjection NOSsa/nOssa (my god), as well as in lines 46 and 52 with $\uparrow$ PÔ and $\uparrow \mathrm{POxa}$ (damn), both described by Marcuschi $(2006,41)$ as interjections which represent frequent discourse markers (marcadores conversacionais) with an exclamative or emphatic function in Brazilian talk. They are usually uttered by recipients to encourage the speaker to proceed with his talk and can be seen as a sign of 'attunement' (sintonia) between the speaker and the participant with regard to their engagement. In L38, he finally exclusively addresses B2 by persistantly shifting his gaze towards him and maintaining eye contact as long as he at least elicits a sign of minimal agreement from him (L39).

Although B2 finally contributes with the emotive interjection nossa (my god, L53) on the verbal level, there is no sign of "mutual monitoring" (Goodwin 1980) on the prosodic level as the interjection is neither accentuated, nor lengthened, but whispered. Also, the nonverbal level is 'silent', i.e., there is, for example, no body movement or nodding, described by Stivers (2008) as one crucial hint for the interlocutor's access to the teller's stance toward the events.

7. That is why Sacks, Schegloff and Jefferson $(1974,718)$ call them 'recompleters'. 
At the end of the sequence, in L56, B3 himself initiates a final stancetaking through a retrospective and summarizing perspective by using a metacommunicative act through which he comes back to the question on the card and questions whether his story really represents a typical misunderstanding or not. After nobody takes the turn at the completion point in L60 só não foi uma si tuação agraDÁvel (it just wasn't a pleasant situation), which is reinforced by a pause of 3.3 seconds in L61, B3 again comes to a conclusion, now on a metalevel, with regard to a possible further response to the question on the card: não me recordo de mais NAda (I don't remember anything else, L63), again followed by a now even more markable pause of 8.3 seconds. Every co-participant lowers their eyes and even B4 stops sending messages via cell phone and establishes eye contact with B3 who in turn picks up her glance and asks if there is any other topic they could talk about, or if they should finish the conversation, underscored by a strikingly strained voice (L65-66).

We have in fact a 'deviant case' of a storytelling which was incrementally expanded as a consequence of the absence of tokens of alignment and affiliation on the part of the co-participants visible on the verbal, vocal, and visual plane. Now, we have to further ask to which extent face issues come into play here if we recall one basic postulate of FCT, namely, that face is a continuous, co-constructed, and ongoing byproduct of interaction defined by the tensional interplay of connectedness and separateness. To a certain extent, I would agree with Goffman to describe this behavior of the interlocutors as a kind of "avoidance process" (Goffman 1967 [1955], 15-16) since they do not actively prevent B3 from moving on with his story but simply minimize their reaction by showing no support to continue. Yet, what is more striking here is that, as a reaction to this, B3 does not avoid or cut off the topic he is talking about but, in contrast, goes into more depth by outlining all details of the story and displaying strong emotional involvement and indignation. In turn, the prolonged silence displayed by the co-participants cannot be simply analyzed in terms of 'negative impoliteness', as a personal strategy of 'withheld politeness' (Culpeper 1996, 357; 2005, 42; Bousfield 2008, 122-123) but rather as a kind of "bone-crushing silence" (silêncio esmagador) in the sense of Marlangeon $(2017,99)$ : While the storyteller tries to overcome the gap by making his narrated actions accountable by justifying his stance (L13, 16, 26-29, 38, 40), B1 and B2 seem to simply wait for him to finish. But why are silence and congealment chosen to calibrate face? Observing the interplay of connectedness and separateness is, however, more helpful because the pivotal point is not about (im)politeness but the calibration of the interaction. B1 and B2 are acting consistently, and, moreover, do not display any open disagreement regarding B3's remarks. Even minimal, they contribute to maintain the conversation as it is reflected in the way B2 displays 
his emotive interjection nossa (my god, L53), which lexically articulates with relational connectedness but prosodically displays separatedness. In the same way, B3's turns oscillate between articulating with connection and with separation: the connection becomes evident by the constant structurally furnishing completion points in which connection face can be created by tokens of affiliation; in contrast, the persistence of those procedures, as well as the emotional involvement included, concurrently articulate with separation by not recognizing the lack of support of the co-participants. This reveals that connection and separation face have to be understood as relational phenomena and not as personal needs.

The microanalytical tools used so far in our analysis are limited to the sequential analysis itself, but in order to at least allude to the richness of face as constituted in social interaction we also have to frame this instance of separation and connection in cultural and contextual terms although we are not able to illustrate but only point to some revealing data in this article: The history of the participants' interaction both prior to and within the talk might be instructive in this respect; also the role of the bystander behind the camera should not be underestimated. As shown in Figure 1, B3 and B4 sit directly across from the camera, while B1 and B2 are located rather collaterally to it. It is crucial to underscore that especially the communicative genre - an elicited conversation - brings unavoidably to the fore the well known 'observer's paradox' (Labov 1972, 209), which is nevertheless not directly related to the present study here: On the one hand, I agree with Duranti $(1997,118)$ who points to the fact that dealing with the paradox means to understand the different ways in which the presence of the camera, tape etc., as well as the imagined researcher, plays a role in the activity that is being studied, and, as a consequence, influences that interaction but not necessarily adulterates it. He also emphasizes that despite that presence, in the end, people are not able to invent social behavior, including language, out of the blue, and that the question of 'being onstage' is finally also a question of degree. On the other hand, for our aims, the 'presence' of the bystander is not seen as a hindrance but in fact quite illuminative. Note that already in the first video, B3 displays the role of presenting more controversial opinions and discusses delicate issues keyed more seriously than the other participants do as is shown, for example, in a sequence analyzed by Schröder (2017, 192-197) where the four exchange students talk about Germans being more direct than Brazilians. As opposed to the other four participants who tell short episodes, B3 reports his story with high negative emotional involvement which becomes increasingly expanded. Also here, he gets no backchanneling signals and is apparently semi-directed to the German researcher, the bystander behind the camera. In contrast, when the others talk about negative first impressions or expectations based on things they have heard from others or read somewhere, they tell these small stories by keying them in a joking manner. Such a mode can be seen as 
part of what I have introduced above as a 'cultural model', meaning that Brazilians frequently tend to tell even negative stories they have experienced as if they were funny anecdotes. In Brazilian Portuguese, there are two terms for 'to play': jogar and brincar. While jogar might be literally translated by 'to play', brincar means far more than only 'to tease sb.:

Os termos 'brincar' e 'brincadeira' são de difícil captação para quem não fala o português, já que não significam apenas 'fazer graça', mas, também, 'agir com facilidade'. Este profundo significado do verbo aparece na expressão 'o brasileiro trabalha brincando e brinca trabalhando' [...] um desprendimento quase alegre, espontâneo, e quase sacro. Significa o homo ludens.

(Flusser 1998, 170) $^{8}$

This special speech style is additionally reflected in the expression rir para não chorar (laugh to avoid crying). The fact that $\mathrm{B} 3$ was revealed to be the one who looked into the camera more often than the others, while the other three partly try to avoid making eye contact, shows that B3 is more engaged and takes the specific task very seriously. He does not only evoke eye contact but also faces the camera more boldly. Interestingly, B1, who is the most invisible for the camera, has a continuing faint smile on his face during the storytelling of $\mathrm{B} 3$, and $\mathrm{B} 4$, when re-entering the scene, also smiles without any discernable reason.

There is a growing field of studies in intercultural pragmatics and face which point to the relation between speech styles and cultural construals, explicitly or implicitly related to the idea of cultural cognition, such as the already mentioned study on kao (face) in Japanese (Haugh 2005), the concept of guanxi (face) in Chinese (Chang 2016), respeto and confianza in Mexican relational communication (Covarrubias 2002) or shekasteh-nafsi (modesty) in Persian (Sharifian 2011). Turning to Brazilian communication and considering the 'playing' attitude described in the previous paragraph, there can be seen a relation to a broader cultural model that anthropological studies have labelled 'Barroque style' (Bastide 1971, 60; Ianni 1993, 120) and 'jeitinho' (a special way of doing things) (DaMatta 1997 [1979]; Ferreira et al. 2012; Barbosa 2006). Bringing out criticism in a more playful way in Brazilian culture is described as pervading everyday conversation and is explained by Sorj $(2000,31)$ in the following way: "É uma cultura pouco propensa à confrontação ou à crítica aberta, já que a pessoa nunca sabe quando poderá 'precisar' da outra num sistema cuja base de funcionamento é o favor e a

8. 'The terms 'brincar' and 'brincadeira' are difficult to understand for whoever does not speak Portuguese since they do not simply mean 'to be funny' but also 'to act easily'. This deep meaning of the verb appears in the expression 'the Brazilian works playing and plays working' [...] a detachment almost hilarious, spontaneous, and almost sacred. It means the homo ludens." 
boa vontade".' This preference for 'being opaque',, also called jeitinho, implies the idea of a certain cultural 'skill' or 'flexibility' developed in order to survive in a non-functional society where there is a necessity for a constant situational adaption and where the line between the private and public sphere is quite blurred. As a consequence, in Brazilian everyday communication direct disagreement is avoided and face saving strategies which show affiliation are preferred (Meireles 2001, 2016); the phatic, poetic, and appellative speech styles are more salient (Schröder 2010); and as a result of the predominance of personal relationships, the 'kind-heartedness' (bondade) which has been condensed in the Brazilian narrative of the 'cordial man' (homem cordial; Buarque de Holanda 1995 [1936], 553-556) sustains the wish for harmonious relations, affiliation, as well as agreement, as can be shown even in today's Brazilian interaction and communication practices (Schröder 2014a; b; Schröder \& Viterbo Lage 2014; Viterbo Lage 2013). This topic was objective of a study on face issues that compared the Argentinean and Brazilian version of Big Brother: Barbosa de Lima (2012) reveals two completely different tactics to get the audience's vote: While the Argentinean habitants of the public housing being filmed were oriented toward an image of being coherent personalities who defend their opinions and stand for their convictions, the Brazilians were more oriented toward an image of being nice and avoiding the expression of strong opinions or the defense of polemic attitudes. In our example, B3 obviously displays a more confrontative style, perhaps also influenced by the task he is involved in, whereas the other Brazilian participants maintain the culturally patterned way of telling amusing 'small stories' when confronted with questions about cultural differences which could go in a negative direction.

\subsection{German example}

The German sequence chosen for comparison unfolds quite differently. While the Brazilian example stems from the second shooting, namely, the shooting which was repeated after the year abroad, the German example has been singled out from the first conversation before the participants' stay in the foreign country. Here, the same questions are asked but still with regard to their expectations.

During the eight minutes before the following sequence, G2 has already twice alluded to his expectation that he will not experience significant cultural differences. Thereby, the questions on the cards are downgraded to a certain extent. He

9. “...it is a culture which is less prone to confrontation or open criticism since one never knows when one will 'need' the other person again in a system whose functional basis are favor and good will." 
is now returning to his claim when the others have just begun to talk about possible divergences concerning the concept of friendship. However, in this case, he evokes a quite opposite reaction, articulated by G1, whereas before nobody had directly challenged his statements:

(2) $2013 \mathrm{MuGe} 01 \quad((15: 15-15: 41))^{10}$

01 G2: also ich würd das genauso sehn wie <<points with his open hand to G3> DU das gesagt hast.>

so I would see this exactly as you have said

das kommt halt (.) ECHT darauf an;

it really depends upon

nicht unbedingt auf die nationalitëT;

not necessarily on the nationality

G1 :

(-) also (.) das is ja individu[ELL ob man sich jetzt ] I mean it's just individual if you

G2 :

((changes viewing direction to G1))

$[<<$ aspirated $>$ ja: : $>\quad]$

yeah

G1 :

$\rightarrow$ 'WEISS ich nich.

I don't know

$\rightarrow$ <<tilting her head side to side> das $k$ es is immer s_sehr

$\rightarrow$ diplomatisch AUS[gedrückt; ]

it's always expressed very diplomatically

aber das sind dann keine freundschaften für_s LE:ben. but those are no friendships for life

G2 is recalling the position that friendship rather builds on individual than national preferences when G1 chimes in by first overlapping with G2 in L05-06 and

10. The video can be watched on https://drive.google.com/file/d/0B4065pqma9RCTTRwYnJpV0Zwdjg/ view?usp=sharing 
interposing the strongly lengthened and deeply aspirated particle ja : : (yeah), followed by the formulation of her doubts on G2's stance introduced by the formulaic expression WEISS ich nicht (I don't know). This turn-initial and preparatory Yes might be classically interpreted as a negative politeness strategy described by Brown and Levinson (1987 [1978], 144) in the following way: "Do not presume/assume (keep ritual distance from the interlocutor)". As in this case, G1 does not position herself unequivocally in opposition to G2. Furthermore, she continues her statement by choosing a metacommunicative act: es ist immer sehr diplomatisch AUSgedrückt (it's always expressed very diplomatically; L09) through which she depersonalizes the addressed interlocutor, an effect stressed in combination with the generic passive construction 'it is + ADV + PART' instead of the specific active construction 'you have + PART + DO + ADV'. On a nonverbal level, this strategy is additionally underpinned by her tilting her head side to side, thus signaling consideration or indecision. The effect is a disclosure of G2's comment, revealed by G2's proper reaction to G1, represented by the nervous laugh token in L10 and his direct short glance into the camera in L11. As Schwitalla $(2001,336)$ shows, such laugh tokens often have the function of reducing the relevance of a problematic assertion and "saving one's own face in moments when something embarrassing has been brought to light". The fact that G2 quickly looks for the camera endorses the fact that his performance has been addressed at the bystander but that at the same time he now feels 'caught'.

After her mitigated introductory turn in L16, G1 finally takes a stance in which she places herself more openly in opposition to G2's position when she picks up an example of cultural relativism, emphasizing its validity by means of the verum accent (Höhle 1992), which she puts on the corpula: †es (.) ! IST! so: (it IS like this). Höhle coins this term to point to the effect caused by placing the main accent on the finite verb, through which the speaker does not present the action or event referred to by the finite verb as new information, but instead merely asserts a supposed truth.

Although at first glance, and by what we have observed so far, this brief analysis seems to more accurately coincide with a traditional occidentally biased face analysis, we should take a closer look and compare the sequence to the Brazilian example: Interestingly, this short moment of 'embarrassment' does not cause any conflict or any 'deviant situation' with regard to the way the sequence proceeds. This could be seen as an indication for how culture plays a role in connection and separation face.

First, it might be helpful to take a brief look at the contextual background: The two students, G1 and G2, know each other very well and are probably in an intimate relationship, which is revealed especially in the second conversation six months later where they talk about their living together in Poland. In this sense, face for the two participants has to also be seen as the interpretation of 
"our-relationship-at-this-moment" (Arundale 2013a, 110). So, the situation could be conceived in terms of trying to tune the right level between two conflicting levels of interaction:

The first level to be considered is the intimate relationship in which the German cultural value of 'coherence' comes into play, along with 'openness', as 'saying what one really thinks' plays an important role: Studies on divergent communication styles have brought out (Schröder 2003, 2010) that the German subjects under analysis tended to assign a higher value to the correspondence between words, thoughts, and acts than the Brazilian subjects in these studies. DaMatta (1997 [1979]) has shown the extent to which the Brazilian concept jeitinho incorporates a culture-specific technique of escaping from direct forms of talk, as we have discussed in the preceding section. By contrast, the cultural value of 'coherence', as well as the open expression of disagreement in German communication is frequently related to the wish to be able to count on one's counterpart's statements as empirical studies revealed especially in opposition to other speech communicties (House 2010; Philburn 2011; Schröder 2014a, 2014b). It might be instructive to take a brief look at the historical background that has favored such a focus on coherence since the beginnings of the functional differentiation of German society starting with the Renaissance: (a) the persistent repercussions of literary language as a kind of 'objectivation' of otherwise fugitive talk, (b) the interiorization process favored by the arising of Protestant values, as well as (c) the increasing dichotomy between public and private life (Elias 1997a, 110; 1997b, 409-420; Luhmann 1989, 130-180; Weber 1991 [1904]), to name just a few important factors. To know that G1 and G2 have an intimate relationship is hence an indispensable detail in the reconstruction of what happens here. Or, to put it in the words of Arundale (2010, 2013a), in order to co-build connectedness on the intimate level, overt disagreement might be an appropriate account. Although G1 uses certain downgraders for expressing her opposing opinion, there is no delay before the production of her disagreement as could be expected in the case of dispreferred activities (Pomerantz 1984, 53).

The second level, which is in conflict with the described first level, is represented by the somehow anonymous public relationship with the other participants (who do not know each other), as well as with the bystander behind the camera constituting the specific communicative genre of 'elicited conversation'. On this level, it might be in fact rude to disagree quite openly and to cause embarrassment in such a way that the social distance of such a discussion could be negatively affected. Again, the Labovian paradox $(1972,209)$ might play a certain role at this point, although the presence of the other participants could cause the same effect. 


\section{Concluding remarks}

As we have seen, FCT appears to be an adequate approach for understanding the phenomenon of face from a communication-based, cultural- and context-dependent analysis of multimodal interaction. As it integrates conversation analysis-grounded principles from a participant's point of view, it represents an epistemical, holistic attempt to overcome the shortcomings of intention-oriented (im)politeness notions of face. The two examples discussed departed from a fine-grained analysis and revealed that a mere person-centered view is too reductive to accurately take into consideration all aspects which mark the situationally and culturally anchored dynamics of talk. According to Arundale, FCT offers a conceptualization of face as relational connection and separation, as endogenous to talk-in-interaction rather than exogenous as in many existing theories.

However, the embedding of the results in the broader context of the history of the whole interaction(s), as well as the history between the interactants themselves, next to the framing of the revealed data with regard to the cultural background, shows us that we have to face the issue that it would be reductive to not take background, as well as theoretical knowledge, into consideration. Nevertheless, as we have seen, although there is an undeniable connection to dualistic categories as established by intercultural communication studies (House 2010; Schröder 2014a; b; Hofstede 1983), such as German directness and explicitness in contrast to Brazilian indirectness and implicitness, those categories alone do not explain how participants orient themselves towards such concepts in concrete talk with regard to each other and the bystander behind the camera when face is negotiated, as well as how the emic cultural concept of face constitutes co-participant's attitudes displayed by connectedness and separation.

\section{Acknowledgments}

First of all, I wish to express my deep gratitude to Robert B. Arundale for his interest in my paper and whose extensive and profound comments helped me improve it substantially. I would further like to thank CNPq (National Council for Scientific and Technological Development) for the support by the Fellowship Program Productivity in Research (2015-2018), FAPEMIG (The Minas Gerais State Research Foundation) for the Fellowship Research Program Minas Gerais (2015-2017 and 2017-2019) CAPES (Coordination for the Improvement of Higher Education Personnel) and the Alexander von Humboldt-Foundation for the one-year financial support within the program Capes-Humboldt Research Fellowship for experienced researchers at the University of Münster. 


\section{Transcription conventions ${ }^{11}$}

$\begin{array}{ll}{[} & ] \\ {[} & ] \\ = & \end{array}$

and_uh

hm_hm

(.)

$(-)$

$(--)$

$(2.0)$

$:,::,:::$

((laughs))

$<<$ laughing $>>$

$<<$ acc $>$

(may i)

(i say/let's say)

ohh hho

(xxx)

acCENT

accEnt

ac!CENT!

?

,

$-$

;

^SO

«SO

'SO

'SO

$\uparrow$

$\downarrow$

overlap and simultaneous talk

fast, immediate continuation with a new turn or

segment (latching)

cliticizations within units

bi-syllabic tokens

micro pause, up to $0.2 \mathrm{sec}$.

short pause of $0.2-0.5 \mathrm{sec}$.

intermediary pause of $0.5-0.8 \mathrm{sec}$.

measured pause of $2.0 \mathrm{sec}$.

lengthening (0.2-0.5 sec.; $0.5-0.8 \mathrm{sec}$; $0.8-1.0 \mathrm{sec}$.)

non-verbal vocal actions and events

para-verbal and non-verbal action as accompanying

speech with indication of scope

accelerando, becoming faster

assumed wording

possible alternatives

in- and outbreaths

one unintelligible syllable

focus accent

secondary accent

extra strong accent

rising to high final pitch movement of intonation unit

rising to mid final pitch movement of intonation unit

level final pitch movement of intonation unit

falling to mid final pitch movement of intonation unit

falling to low final pitch movement of intonation unit

rising-falling accent pitch movement

falling-rising accent pitch movement

rising accent pitch movement

falling accent pitch movement

pitch upstep

pitch downstep

11. short, adopted version of GAT2 according to Selting et al. (2011). 


\section{References}

Arundale, Robert B. 1999. "An Alternative Model and Ideology of Communication for an Alternative to Politeness Theory." Pragmatics 9 (1): 119-153. https://doi.org/10.1075/prag.9.1.07aru

Arundale, Robert B. 2008. "Relating Japanese Emic Face Concepts and Face Constituting Theory." University of Alaska Fairbanks, unpublished manuscript.

Arundale, Robert B. 2009. "Face as Emergent in Interpersonal Communication: An Alternative to Goffman." In Face, Communication, and Social Interaction, ed. by Francesca BargielaChiappini, and Michael Haugh, 33-54. London: Equinox.

Arundale, Robert B. 2010. "Constituting Face in Conversation: Face, Facework, and Interactional Achievement." Journal of Pragmatics 42: 2078-2105. https://doi.org/10.1016/j.pragma.2009.12.021

Arundale, Robert B. 2013a. "Face as a Research Focus in Interpersonal Pragmatics: Relational and Emic Perspectives." Journal of Pragmatics 58: 108-120. https://doi.org/10.1016/j.pragma.2013.05.013

Arundale, Robert B. 2013b. "Is Face the Best Metaphor? / ¿Es imagen social la mejor metáfora?" Pragmática Sociocultural / Sociocultural Pragmatics. Revista Internacional sobre Lingüistica del Español / An International Journal of Spanish Linguistics 1(2): 282-297.

Atkinson, Maxwell, and John Heritage. 1984. "Preference Organization." In Strutures of Social Action. Studies in Conversation Analysis, ed. by Maxwell Atkinson, and John Heritage, 5356. Cambridge: Cambridge University Press.

Barbosa de Lima, Fábio. 2012. "Parecer bom x parecer justo - o pedido de desculpas na gestão da imagem nas interações mediáticas.” Dissertação de Mestrado. São Paulo: Universidade de São Paulo.

Barbora, Livia. 2006. O jeitinho brasileiro. A arte de ser mais igual do que os outros. Rio de Janeiro: Elsevier; Editora Campus.

Bargiela-Chiappini, Francesca. 2003. "Face and Politeness: New (Insights) for Old (Concepts)." Journal of Pragmatics 35: 1453-1469. https://doi.org/10.1016/So378-2166(02)00173-X

Bastide, Roger. 1971. Brasil - Terra de Contrastes. São Paulo: Difusão Européia do Livro.

Baxter, Leslie A., and Barbara M. Montgomery. 1996. Relating: Dialogues and Dialectics. New York: Guilford.

Bousfeld, Derek. 2008. Impoliteness in Interaction. Amsterdam: John Benjamins. https://doi.org/10.1075/pbns.167

Bravo, Diana. 2008. "(Im)Politeness in Spanish-Speaking Socio-Cultural Contexts: Introduction." Pragmatics 28(4): 563-576. https://doi.org/10.1075/prag.18.4.01bra

Brown, Penelope, and Stephen Levinson. 1987[1978]. Politeness: Some Universals in Language Usage. Cambridge: Cambridge University Press.

Buarque de Holanda, Sérgio. 1995 [1936]. “O Homem Cordial.” In Vanguardas Latino-Americanas. Polêmicas, Manifestos e Textos Críticos, ed. by Jorge Schwartz, 553-556. São Paulo: Editora da Universidade de São Paulo.

Bühler, Karl. 1982 [1934]. Sprachtheorie: die Darstellungsfunktion der Sprache. Stuttgart: Fischer. Chang, Wei-Lin Melody. 2016. Face and Face Practices in Chinese Talk-in-Interaction. London: Equinox.

Covarrubias, Patricia O. 2002. Culture, Communication and Cooperation: Interpersonal Relations and Pronominal Address in a Mexican Organization. Oxford: Rowman \& Littlefield. 
Culpeper, Jonathan, 1996. “Towards an Anatomy of Impoliteness." Journal of Pragmatics 25: 349-367. https://doi.org/10.1016/0378-2166(95)00014-3

Culpeper, Jonathan. 2005. "Impoliteness and the Weakest Link." Journal of Politeness Research 1 (1): 35-72. https://doi.org/10.1515/jplr.2005.1.1.35

DaMatta, Roberto. 1997 [1979]. Carnavais, malandros e heróis. Para uma sociologia do Dilema Brasileiro. Rio de Janeiro: Rocco.

Drew, Paul, and Traci Walker. 2009. "Going too Far: Complaining, Escalating and Disaffiliation." Journal of Pragmatics 41: 2400-2414. https://doi.org/10.1016/j.pragma.2008.09.046

Duranti, Alessandro. 1997. Linguistic Anthropology. Cambridge: Cambridge University Press. https://doi.org/10.1017/CBO9780511810190

Elias, Norbert. 1997a. Über den Prozeß der Zivilisation. Soziogenetische und psychogenetische Untersuchungen. Erster Band. Wandlungen des Verhaltens in den weltlichen Oberschichten des Abendlandes. Frankfurt am Main: Suhrkamp.

Elias, Norbert. 1997b. Über den Prozeß der Zivilisation. Soziogenetische und psychogenetische Untersuchungen. Zweiter Band. Wandlungen der Gesellschaft - Entwurf zu einer Theorie der Zivilisation. Frankfurt am Main: Suhrkamp.

Fant, Lars. 2006. "National Cultural Norms or Activity Type Conventions? Negotiation Talk and Informal Conversation Among Swedes and Spaniards." SYNAPS 19: 1-22.

Ferreira, Maria C. et al. 2012. "Unraveling the Mystery of Brazilian Jeitinho: A Cultural Exploration of Social Norms." Personality and Social Psychology Bulletin 38(3): 331-344. https://doi.org/10.1177/0146167211427148

Flusser, Vilém. 1998. Fenomenologia do Brasileiro: Em Busca de um Novo Homem. Rio de Janeiro: Editora da Universidade do Estado do Rio de Janeiro.

Goffman, Erving. 1967 [1955]. "On Face-Work: An Analysis of Ritual Elements in Social Interaction." In Interaction Ritual. Essays on Face-to-Face Behavior, ed. by Erving Goffman, 5-45. New York: Pantheon Books.

Goffman, Erving. 1981. Forms of Talk. Philadelphia: University of Pennsylvania Press.

Goodwin, Marjorie Harness. 1980. "Processes of Mutual Monitoring Implicated in the Production of Description Sequences." Sociological Inquiry 50: 303-317. https://doi.org/10.1111/j.1475-682X.1980.tbooo24.X

Günthner, Susanne. 1999. “Thematisierung moralischer Normen in der interkulturellen Kommunikation." In Kommunikative Konstruktion von Moral, ed. by Jörg Bergmann, and Thomas Luckmann, 325-351. Opladen: Westdeutscher Verlag.

Haugh, Michael. 2005. "The Importance of 'Place' in Japanese Politeness: Implications for CrossCultural and Intercultural Analyses." Intercultural Pragmatics 2: 41-68. https://doi.org/10.1515/iprg.2005.2.1.41

Haugh, Michael. 2007. "Emic Conceptualisations of (Im)politeness and Face in Japanese: Implications for the Discursive Negotiation of Second Language Learner Identities." Journal of Pragmatics 39 (4): 657-680. https://doi.org/10.1016/j.pragma.2006.12.005

Haugh, Michael. 2010. "Jocular Mockery, (Dis)affiliation, and Face." Journal of Pragmatics 42: 2106-2119. https://doi.org/10.1016/j.pragma.2009.12.018

Haugh, Michael. 2017. "Jocular Language Play, Social Action and (Dis)affiliation in Conversational Interaction." In Multiple perspectives on language play, ed. by Nancy Bell, 143-168. Boston, MA: De Gruyter Mouton.

Hayashi, Makoto. 2013. "Turn Allocation and Turn Sharing." In The Handbook of Conversation Analysis, ed. by Jack Sidnell, and Tanya Stivers, 167-190. Malden, Oxford, West Sussex: Wiley-Blackwell. 
Henne, Helmut, and Helmut Rehbock. 2001. Einführung in die Gesprächsanalyse. Berlin, New York: De Gruyter. https://doi.org/10.1515/9783110906189

Hofstede, Geert. 1983. "National Culture in Four Dimensions. A Research Based Theory of Cultural Differences among Nations." International Studies of Management and Organization 13: 46-74. https://doi.org/10.1080/00208825.1983.11656358

Höhle, Tilmann N. 1992. "Über Verum-Fokus im Deutschen.” In Informationsstruktur und Grammatik, ed. by Joachim Jacobs, 112-141. Opladen: Westdeutscher Verlag. https://doi.org/10.1007/978-3-663-12176-3_5

House, Juliane. 2010. "Impoliteness in Germany: Intercultural Encounters in Everyday and Instutional Talk." Intercultural Pragmatics 7(4): 561-595. https://doi.org/10.1515/iprg.2010.026 Ianni, Octavio. 1993. O Labirinto Latino-Americano. Petrópolis: Vozes.

Kasper, Gabriele. 2008. “Data Collection in Pragmatics Research.” In Culturally Speaking. Culture, Communication and Politeness Theory, ed. by Helen Spencer-Oatey, 279-303. London: Continuum.

Kecskes, Istvan. 2014. Intercultural Pragmatics. New York, Oxford: Oxford University Press.

Kerbrat-Orecchioni, Catherine. 2017. "Abordagem intercultural da polidez linguística: problemas teóricas e estudo de caso." In Descortesia e Cortesia: Expressões de Culturas, ed. by Ana Lúcia Tinoco Cabral, Isabel Roboredo Seara, and Manoel Francisco Guaranha, 17-55. São Paulo: Cortez.

Labov, William. 1972. Sociolinguistic Patterns. Philadelphia: University of Pennsylvania.

Lerner, Gene H. 1992. "Assisted Storytelling: Deploying Shared Knowledge as a Practical Matter." Qualitative Sociology 15(3): 247-271. https://doi.org/10.1007/BFoo990328

Lerner, Gene H. 2002. "Turn-Sharing: The Choral Co-Production of Talk-in-Interaction.” In The Language of Turn and Sequence, Cecilia Ford, Barbara A. Fox, and Sandra A. Thompson, 225-256. Oxford: Oxford University Press.

Luhmann, Niklas. 1989. "Gesellschaftsstruktur und Semantik. Studien zur Wissenssoziologie der modernen Gesellschaft. Band 3.” Franfurt am Main: Suhrkamp.

Marcuschi, Luiz A. 2006. "Atividades de compreensão na interação verbal." In Estudos de Língua Falada. Variações e Confrontos, ed. by Dino Preti, 15-45. São Paulo: Associação Editorial Humanitas.

Marlangeon, Silvia Kaul de. 2017. "Contribuições para o estudo da descortesia verbal." In Descortesia e Cortesia: Expressões de Cultura, ed. by Ana Lúcia Tinoco Cabral, Isabel Roboredo Seara, and Manoel Francisco Guaranha, 93-108. São Paulo: Cortez.

Mead, George H. 1967 [1932]. Mind, Self, \& Society from the Standpoint of a Social Behaviorist. Works of George Herbert Mead. Volume 1, ed. by Charles W. Morris. Chicago, London: The University of Chicago Press.

Meireles, Selma Martins. 2001. "A negação sintática em diálogos do alemão e do português do Brasil.“ Pandaemonium Germanicum 5: 139-168. https://doi.org/10.11606/1982-8837.pg.2001.64331

Meireles, Selma M. 2016. "Uso de verbos com valor epistêmico no Trabalho da Face por falantes alemães e brasileiros." In Anais do I Congresso da ABEG, ed. by Helmut P. E. Galle, and S. Valéria, 395-401. São Paulo: ABEG Editora Associação Brasileira de Estudos Germanísticos (ABEG).

Philburn, Rob. 2011. "Aspects of English and German Sociable Selfhood." In Intercultural competence: concepts, challenges, evaluations, ed. by Arnd Witte, and Theo Harden, 411-435. Bern: Peter Lang. 
Pomerantz, Anita. 1984. "Agreeing and Disagreeing with Assessments: Some Features of Preferred/Dispreferred Turn Shapes." In Structures of Social Action. Studies in Conversation Analysis, ed. by Maxwell Atkinson, and John Heritage, 57-101. Cambridge: Cambridge University Press.

Sacks, Harvey, Emanuel A. Schegloff, and Gail Jefferson. 1974. "A Simplest Systematics for the Organization of Turn-Taking for Conversation." Language 50: 696-735.

https://doi.org/10.1353/lan.1974.0010

Schegloff, Emanuel. 1982. "Discourse as an Interactional Achievement: Some Uses of 'uh huh' and Other Things that Come Between Sentences." In Analyzing Discourse: Taxt and Talk, ed. by Deborah Tannen, 71-93. Washington: Georgetown University Press.

Schmidt, Thomas, and Kai Wörner. 2009. "EXMARaLDA - Creating, Analysing and Sharing Spoken Language Corpora for Pragmatic Research.” Pragmatics 19: 565-582.

https://doi.org/10.1075/prag.19.4.06sch

Schröder, Ulrike. 2003. Brasilianische und deutsche Wirklichkeiten. Eine vergleichende Fallstudie zu kommunikativ erzeugten Sinnwelten. Wiesbaden: Deutscher Universitätsverlag.

Schröder, Ulrike. 2010. "Speech Styles and Functions of Speech From a Cross-Cultural Perspective." Journal of Pragmatics 42: 466-476. https://doi.org/10.1016/j.pragma.2009.06.014

Schröder, Ulrike. 2014a. “The Interplay of Politeness, Conflict Styles, Rapport Management and Metacommunication in Brazilian-German Interaction". Intercultural Pragmatics 11: 57-82. https://doi.org/10.1515/ip-2014-0003

Schröder, Ulrike. 2014b. "Interkulturelle Kommunikation zwischen Deutschen und Brasilianern im Lichte von Strategien der (Un-)höflichkeit, divergierenden Konfliktstilen und Formen des Beziehungsmanagements." In Interkulturalität unter dem Blickwinkel von Semantik und Pragmatik, ed. by Csaba Földes, 207-224. Tübingen: Narr, Francke Attempto.

Schröder, Ulrike. 2017. "The Interactive (Self-)reflexive Construction of Culture-Related Key Words." In Current Issues in Intercultural Pragmatics, ed. by Istvan Kecskes, and Stavros Assimakopoulos, 182-205. Amsterdam: John Benjamins.

https://doi.org/10.1075/pbns.274.09sch

Schröder, Ulrike, and Carolina de Viterbo Lage. 2014. "Estratégias de polidez em momentos de dissensão: análise de uma interação entre estudantes brasileiros e alemães." Revista de Estudos da Linguagem 22 (1): 153-179. https://doi.org/10.17851/2237-2083.22.1.153-179

Schwitalla, Joachim. 2001. "Lächelndes Sprechen und Lachen als Kontextualisierungsverfahren." In Sprachkontakt, -vergleich, -variation, ed. by Adamzik Kirsten, and Helen Christen, 325344. Tübingen: Niemeyer.

Selting, Margret. 1994. "Emphatic Speech Style: With Special Focus on the Prosodic Signaling of Heightened Emotive Involvement in Conversation." Journal of Pragmatics 22: 375-408. https://doi.org/10.1016/0378-2166(94)90116-3

Selting, Margret et al. 2011. "A System for Transcribing Talk-in-Interaction: GAT 2; translated and adapted for English by Elizabeth Couper-Kuhlen and Dagmar Barth-Weingarten." Gesprächsforschung - Online-Zeitschrift zur verbalen Interaktion 12: 1-51; http://www. gespraechsforschung-ozs.de/fileadmin/dateien/heft2011/px-gat2-englisch.pdf; last accessed on September 30, 2017.

Senft, Gunter. 1995. “Elicitation.” In Handbook of Pragmatics: Manual, ed. by Jef Verschueren, Jan-Ola Östman, and Jan Blommaert, 577-581. Amsterdam: John Benjamins. https://doi.org/10.1075/hop.m.eli1

Sidnell, Jack. 2010. Conversation Analysis: An Introduction. Malden, Oxford, West Sussex: WileyBlackwell. 
Sharifian, Farzad. 2011. Cultural Conceptualisations and Language. Amsterdam, Philadelphia: John Benjamins Publishing. https://doi.org/10.1075/clscc.1

Sharifian, Farzad. 2015. "Cultural Linguistics." In The Routledge Handbook of Language and Culture, ed. by Farzad Sharifian, 473-492. New York: Routledge.

Sorj, Bernardo. 2000. A Nova Sociedade Brasileira. Rio de Janeiro: Jorge Zahar Editor Ltda.

Spencer-Oatey, Helen. 2008. "Introduction.” In Culturally Speaking: Culture, Communication and Politeness Theory, ed. by Helen Spencer-Oatey, 1-8. London: Continuum.

Stivers, Tanya. 2008. "When Nodding is a Token of Affiliation." Research on Language \& Social Interaction 41(1): 31-57. https://doi.org/10.1080/08351810701691123

Stivers, Tanya. 2013. "Sequence Organization." In The Handbook of Conversation Analysis, ed. by Jack Sidnell, and Tanya Stivers, 191-209. Malden, Oxford, West Sussex: Wiley-Blackwell.

Ting-Toomey, Stella, and John Oetzel. 2007. "Intercultural Conflict: A Culture-Based Situational Model." In Intercultural Communication. A Text with Readings, ed. by Pamela J. Cooper, Carolyn Calloway-Thomas, and Cheri J. Simonds, 121-130. Boston: Pearson Education.

Triandis, Harry C. 1984. "A Theoretical Framework for the More Efficient Construction of Culture Assimilators." International Journal of Intercultural Relations 8: 301-330. https://doi.org/10.1016/0147-1767(84)90029-4

Ungeheuer, Gerold. 2010 [1983]. Einführung in die Kommunikationstheorie, ed. by Karin Kolb, Jens Loenhoff, and H. Walter Schmitz. Münster: Nodus Publikationen.

Ungeheuer, Gerold. 1987. "Vor-Urteile über Sprechen, Mitteilen, Verstehen." In Kommunikationstheoretische Schriften I: Sprechen, Mitteilen, Verstehen, ed. by Johann G. Juchem, 290338. Aachen: Rader Publikationen.

Viterbo Lage, Caroline de. 2013. Comunicação Interpessoal e Intercultural entre Brasileiros e Alemães: Análise dos Momentos de Conflito. Belo Horizonte: Universidade Federal de Minas Gerais, Dissertação de Mestrado.

Weber, Max. 1991 [1904]. Die protestantische Ethik I. Eine Aufsatzsammlung, ed. by Johannes Winckelmann. Gütersloh: Gütersloher Verlagshaus Gerd Mohn.

Wegener, Philipp. 1991 [1885]. Untersuchungen über die Grundfragen des Sprachlebens, ed. by Konrad Koerner. Amsterdam: John Benjamins. https://doi.org/10.1075/10.1075/cipl.5

\section{Author's address}

Ulrike Schröder

Faculdade de Letras

Universidade Federal de Minas Gerais

Av. Antônio Carlos, 6627

CEP 31270-901 Belo Horizonte - MG

Brazil

schroederulrike@gmx.com 